Ethiopian Journal of Environmental Studies \& Management 7(5): 532 - 547, 2014

ISSN:1998-0507

doi: http://dx.doi.org/10.4314/ejesm.v7i5.7

Submitted: May 31, 2014

Accepted: September 04, 2014

\title{
POST-ADAPTATION VULNERABILITY OF CEREALS TO RAINFALL AND TEMPERATURE VARIABILITY IN THE FEDERAL CAPITAL TERRITORY OF NIGERIA
}

*ISHAYA, S., HASSAN, S.M AND JAMES, S.E.

Department of Geography and Environmental Management, University of Abuja, Nigeria

\begin{abstract}
This study assessed the vulnerability of cereals yield to climate change using an integrated and multi-scale quantitative approach. The objectives of this study include determining the level of climate variability, assessment of cereals yield sensitivity index, determining climate exposure index, determining adaptive capacity of farmers, assessment of the post adaptation vulnerability of cereals yield to climate change. Socioeconomic data were obtained through administration of questionnaires. Thirty years data of temperature and rainfall as well as fifteen years data of annual cereals yield were used. Mean and standard deviation, standardized coefficient of skewness $\left(Z_{1}\right)$ and kurtosis $\left(Z_{2}\right)$, simple linear regression and time series statistics analysis were used in this study for the analysis of data. Finding depicts that the exposure index of rainfall is low but high for temperature. Cereals sensitivity index/degree of crop yield failure is more from 2000 - 2010 and significant difference was observed in sensitivity index for all the cereals. Adaptive capacity of farmers to climate change is high in Bwari and AMAC but low in Gwagwalada, Kuje, Abaji and Kwali. Post adaptation vulnerability of maize, rice and millet yield to rainfall and temperature is low in AMAC and Bwari but high in Gwagwalada, Kwali, Abaji and Kuje. Post adaptation vulnerability of sorghum in relation to rainfall is low in all the area councils in the FCT except Abaji. In relation to temperature, vulnerability of sorghum is high in Abaji and Kuje but low in AMAC, Gwagwalada, Kwali and Bwari. It was recommended that there is need to place climate change within the top priority of developmental context, and provision and infrastructure as well as reliable agricultural extension service.
\end{abstract}

Key Words: Cereals, Post-Adaptation, Vulnerability, Rainfall, Temperature, Variability, FCT

\section{Introduction}

Over the last two decades, climate change/variability remains one of the most serious environmental, social and economic challenges on a global scale (Scholze et al., 2006; Mendelsohn et al., 2006). Climate change have significant impacts on ecosystems and their services and consequently on human wellbeing as it was identified as one of the five main direct drivers causing ecosystem services decline across the globe (Millennium Ecosystem, 2005).
In the Subtropical region and most developing countries of the world the agricultural sector is the most vulnerable to climate change. Landless farmers, livestock keepers, people in poor health, undernourished, low economic status, women and children including women headed households, those with low level of education, low income earners and those with low technological know-how are more exposed to the risk of climate change (Barber, 2003). In Nigeria, agriculture remains a major source of food, industrial

*Corresponding Author: Ishaya, S.

Email: ishayasunny@yahoo.com 
raw materials and means of earning foreign exchange. The agricultural sector employs close to $70 \%$ of the Nigerian population (Hassan et al., 2011). Agricultural practice in Nigeria is mainly rain-fed and therefore vulnerable to the impacts of climate change/variability. Particularly, cereals (maize, sorghum, millet and rice) production, which are the major crops produced in the north of the confluence of river Niger and Benue, are mostly vulnerable to climate change/variability (Etiosa and Matthew, 2007). In the developing countries, vulnerability can be further increased by existing stress factors, such as endemic poverty, limited access to capital, ecosystem degradation, high risk areas, lower adaptive capacity, disasters and conflicts and lack of effective response from the side of the government (IPCC, 2001a; UNSG, 2000).

Agricultural production, including access to food, in many African countries and regions is projected to be severely compromised by climate variability and change (NRDC, 2007; Jan and Anja, 2007). The area suitable for agriculture, the length of growing seasons and yield potential, particularly along the margins of semi-arid and arid areas, are expected to decrease. This would further adversely affect food security and exacerbate malnutrition in the continent. In some countries, yields from rain-fed agriculture could be reduced by up to $50 \%$ by 2020 (IPCC, 2007).

According to Balogun (2001) agriculture is regarded as an essential way of life of the indigenous people in Abuja. It is also strongly believed by the people that agriculture is the most honorable productive activity practiced by up to $85 \%$ of the indigenous inhabitants and it remains the mainstay of rural people and economy. Most of the crops produced by these farmers are cereals (maize, guinea corn, millet, and rice) and yams. In recent times, the FCT suffers a lot from erratic weather patterns such as heat stress, longer dry seasons and uncertain rainfall patterns putting areas that depend strictly on rainfall for crop production at risk (Hassan, 2008). Cereals production in Abuja the Federal Capital Territory of Nigeria is likely to be sensitive to climate changes due to the intra-seasonal and inter-annual variability of rainfall, poor starting conditions, limited adaptation options for smallholders, subsistence nature of farming, the limited information on climate change and adaptation measures just like in other parts of Nigeria and the tropics. This means that, cereals production in the FCT may not be an exception to impact of climate change.

In recent years, reports by Lecocq and Shalizi (2007); Rachel (2008); Muyeye and Jesper (2010) have attempted to assess the vulnerability of communities or farming systems to climate change using a variety of different approaches. Lobell et al., (2008); Challinor et al., (2009); have applied quantitative crop modeling to identify areas that harvests may decline or increase due to climate change. These quantitative models offer useful communication and visual tools to policy makers by making complex scientific data more comprehensible (IFPRI, 2009). However, crop models as vulnerability assessment tools are subject to various limitations. For instance, the adaptations included in most crop models are hypothetical and often assumes either "no adaptation or optimal adaptation by farmers. Heru (2007) assess vulnerability by estimating indices or averages for selected indicators.

Gbetibouo et al. (2010) observed that indicators are useful for monitoring and studying trends and exploring conceptual frameworks and are also applicable across different scales including the household, district, region and nation. Despite the potential of indicators, they are constrained by deficiency in information on selection of reliable variables and the relative weightings 
needed to establish a vulnerability index (Heru, 2007). The application of the vulnerability integrated method (biophysical and social determinants of vulnerability) method is useful because it uses rainfall and crop yield data to ascertain the characteristics of vulnerable and resilient cases in an area. Its main limitation is that, the method considers only exposure and sensitivity components of vulnerability neglecting adaptive capacity which is equally very important.

According to Smit et al. (2000), vulnerability is distinguished as "preadaptation vulnerability" from "postadaptation vulnerability". The pre-adaptation vulnerability is always important in unavailing the year to year vulnerability of crop to climate change/variability where adaptation data are not available. The postadaptation is valuable for it integrates the three indicators of vulnerability (exposure index, sensitivity index and adaptive capacity) which allows for areal assessment of vulnerability (Jaymie et al., 2004). This study was propelled to unveil the post adaptation of cereals vulnerability in the FCT.

\section{The Study Area}

The Federal Capital Territory of Nigeria is located between latitudes $8^{\circ} 25^{\prime}$ and $9^{\circ} 25^{\prime}$ Northof the equator and longitudes $6^{\circ} 45^{\prime}$ and $7^{\circ} 45^{\prime}$ east of Greenwich Meridian. The territory covers an area of 8,000 square kilometers and occupies about $0.87 \%$ of Nigeria. The territory is situated wholly within the region generally referred to as the "Middle Belt" (Balogun, 2001), and is bordered on all sides by four states namely Niger, Nasarawa, Kogi and Kaduna. The FCT is made up six area councils (AMAC, Gwagwalada, Bwari, Kuje, Kwali and Abaji). The climate of the FCT is predominant wet and dry season characteristics. Temperature in the FCT ranges between $30^{\circ} \mathrm{C}-37.0^{\circ} \mathrm{C}$ yearly with maximum temperature in March and mean total annual rainfall of approximately $1,650 \mathrm{~mm}$ per annum with large amount of the annual rains in the months of July to September. The dominant drainage systems in the FCT are River Usuma and River Gurara. The vegetation in the FCT is not uniform in nature with shrub savannah vegetation type dominating the northern part of the FCT while riparian vegetation are common on the flood plains of River Gurara and Usuma (Adakayi, 2000). In the southern part of the FCT and on the foothill of most of the mountainous areas gallery vegetation dominates (Balogun, 2001). The 2006 population census put the population of the FCT as 1,405,201 with the male population as 740,489 and the female population to be 664,712 .

\section{Methodology}

Thirty years rainfall and temperature data of the study was obtained from the Nigeria Meteorological Agency (NIMET) and yield data for cereals for the FCT over a period of fifteen years (1996 to 2010) was obtained from Abuja Agricultural Development Programme (AADP) and National Programme for Agriculture and Food Security (NPAFS).

\section{Preliminary Analysis}

In ascertaining the nature of trends and measurement of variability of both rainfall and mean temperature the standard deviation a measure of variability that is more convenient than percentile differences due to its in-depth investigation and analysis of statistical data was utilized. This is because Standard deviation has the potential to provide a result of deviation from normal (average) and means ( $\square$ ) for rainfall temperature data. The mean in this study is obtained thus:

$$
\bar{n}=\frac{\sum H^{\prime}}{\eta}
$$

The standard deviation $(\sigma)$ is given by the formula: 
$d=\sqrt{\frac{x_{1}^{2}+x_{2}^{2}+\ldots+x_{n}^{2}}{n}}$

The equation for the trend line was used to calculate the expected yield in each year as a linear model of time series of actual yield. According to Temi (2006) in climatology trend/time series is familiarized to depict overall increase or decrease in climatic phenomenon over time. In climatology, time series can be in form of secular trend, cyclical changes, seasonal changes, or random residual (regular fluctuation).

Method of Determining the Sensitivity of Cereals Yield to Climate Variability

In determining cereals sensitivity to climate variability, cereals yield sensitivity index were calculated for maize, sorghum, rice and millet. The yield data for cereals for the FCT over a period of fifteen years (1996 to 2010) was obtained from Abuja Agricultural Development Programme (AADP) and National Programme for Agriculture and Food Security (NPAFS). The period1996-2010 was considered due data availability. Sensitivity index for maize, sorghum, rice and millet yield were calculated using linear trend for the FCT from 1996 to 2010. The actual cereals yield was then divided by expected cereals yield for each year to generate a crop yield sensitivity index (See equation 3 below).

Crop Yield Sensitivity Index =

$=\frac{\text { Actual yiel d }}{\text { Expected yi eld }} \ldots \ldots \ldots \ldots \ldots . . .3$

Method of Determining Exposure Index of Rainfall and Temperature

In determining exposure index, the procedures followed that which was developed by Simelton et al. (2009) and expanded by Philip et al. (2011) in calculating exposure index. In carrying out this, the monthly rainfall and temperature data for the FCT was obtained from Nigerian Meteorological Agency (NIMET) for thirty years period (1982-2011) was used. The use of the thirty years monthly rainfall and temperature data helped to eliminate year-toyear variation which is considered significant to agro-meteorological planning and analysis. In developing the exposure index, the mean of 30 years rainfall and temperature period for seven months period (April to October) from 1982 - 2011 was divided by each year's average rainfall/temperature for the period between April to October which represents the growing season for all cereals in the study area (equation 4 below).

Exposure Index $=\frac{\text { Mean long-term growing season rainfall/temperature for } 1982-2011}{\text { Mean growing geason rainfall/temperature for each year } 1995-2010}$.......... 4

Rainfall exposure index and temperature exposure index were determined because they remain the most influential climatic variable for agricultural productivity (Hassan, 2008). It has been agreed by many scholars that crop yield is highly affected by rainfall and temperature anomaly induced by climate change/variability.

\section{Method of Determining Adaptive Capacity towards Climate Change}

Gbetibouo et al. (2010) and Temesgen et al. (2008) opined that climate change adaptive capacity depends on five farmers' livelihood assets: wealth, farm inputs, availability of infrastructures and institutions, potential for irrigation and literacy level.

Adaptive Capacity = Literacy level + potential for irrigation + Availability of infrastructures + farm inputs/5 or (100Poverty Rate)/100 ........... 5

\section{Post-Adaptation Vulnerability of Cereals Vulnerability to Climate change/Variability}

Employing the results of the exposure index, sensitivity index and adaptive capacity, vulnerability index showing the 
level of vulnerability among the six area councils of the FCT was carried out. Low vulnerability of an area cereal yield to climate change/variability was hypothesized to be as a result of high levels of adaptive capacity of the area which is depicting the socio-economic situations of the area. In the other hand, where vulnerability of cereals to climate change/variability is high in an area council, it means that, the level of adaptive capacity is low in such an area council. Despite the limitations of this method, it is very useful for its incorporation of rainfall/temperature, crop yield data and socioeconomic indicators/adaptive capacity in determine vulnerability.

The vulnerability of cereals production in the FCT and the various Area Councils was determined using equation 6 below:

Vulnerability $=$ [adaptive capacity- $($ Cereals yield sensitivity index + exposure index)]... 6

\section{Results and Discussion}

Vulnerability is contingent on estimates of the potential climate change and adaptive responses. In other words, "the level of vulnerability is determined by the adverse consequences that remain after the process of adaptation has taken place" (Kelly and Adger 2000).

\section{Rainfall and Mean Temperature Growing} Season Exposure Index

As mentioned in the methodology, the estimation of exposure to climate change/variability is this study followed the procedures developed by Simelton et al. (2009) and adopted by Philip et al. (2011). Rainfall and temperature scenarios are the most important climatological determinants of crop yield, the distribution of rainfall and temperature on monthly bases is critical in plant development and crop yield (Hassan, 2008).

Prior to the above mentioned, the exposure indexes from temperature and rainfall variables were measured and findings shows that in the year 1996, 1998, 1999, 2002, 2003, 2004, 2005, 2008, 2009 and 2010 the exposure index of rainfall is low but high in 1997, 2000, 2006 and 2007. It is only in the year 2001 that the rainfall exposure index is fairly high. Apart from the year 1996, 1997 and 2008 which the temperature exposure index is fairly high, the rest of the years within the study period have low temperature exposure index (Table 1).

Table 1: Rainfall and Temperature Exposure Index from 1996 to 2010

\begin{tabular}{lllll}
\hline Year & $\begin{array}{l}\text { Rainfall } \\
\text { Index }\end{array}$ & $\begin{array}{l}\text { Exposure } \\
\text { Exposure }\end{array}$ & $\begin{array}{l}\text { Temperature } \\
\text { Index }\end{array}$ & $\begin{array}{l}\text { Exposure } \\
\text { Temperature Degree of } \\
\text { Exposure }\end{array}$ \\
\hline 1996 & 0.9931 & Low & 1.0086 & Fairly High \\
1997 & 1.0639 & High & 1.0046 & Fairly High \\
1998 & 0.9674 & Low & 0.9859 & Low \\
1999 & 0.8477 & Low & 0.9971 & Low \\
2000 & 1.1583 & High & 0.9953 & Low \\
2001 & 1.0045 & Fairly High & 0.9924 & Low \\
2002 & 0.7458 & Low & 0.9843 & Low \\
2003 & 0.9142 & Low & 0.9825 & Low \\
2004 & 0.9116 & Low & 0.9900 & Low \\
2005 & 0.9392 & Low & 0.9841 & Low \\
2006 & 1.1326 & High & 0.9820 & Low \\
2007 & 1.1004 & High & 0.9961 & Low \\
2008 & 0.8737 & Low & 1.0076 & Fairly High \\
2009 & 0.8531 & Low & 0.9799 & Low \\
2010 & 0.8512 & Low & 0.9906 & Low \\
Mean & 0.957113 & Low & 0.992067 & Low \\
\hline
\end{tabular}


Sensitivity Index of Cereals (Maize, Sorghum, Rice and Millet) to Climate Change/Variability

The result of sensitivity index between1996-2010 for maize yield shows variation with the degree of crop yield failure to be low from the years $1996-2003$ and fairly high in the year 2004. High degree of crop failure was experienced from 2005 -
2010 (see table 2). In evaluating the differences in the average annual yield in the different years, findings show that there is significant difference in the Sensitivity Index of maize yield from $1996-2010\left(\mathbf{X}^{2}\right)$ table values at $0.05(5 \%)$ and $0.01(1 \%)$ are 23.685 and 29.141 respectively are lower than the calculated value (232.783).

Table 2: Cereals Sensitivity Index

\begin{tabular}{|c|c|c|c|c|c|c|c|c|}
\hline \multirow[t]{2}{*}{ S/No } & \multicolumn{2}{|l|}{ Maize } & \multicolumn{2}{|c|}{ Sorghum } & \multicolumn{2}{|c|}{ Rice Sensitivity Index } & \multicolumn{2}{|l|}{ Millet } \\
\hline & SI & DOCF & SI & DOCF & SI & DOCF & SI & DOCF \\
\hline 1996 & 0.8378 & Low & 0.8516 & Low & 0.8965 & Low & 0.9598 & Low \\
\hline 1997 & 0.8420 & Low & 0.8663 & Low & 0.9483 & Low & 0.9572 & Low \\
\hline 1998 & 0.8518 & Low & 0.9009 & Low & 0.9558 & Low & 0.9812 & Low \\
\hline 1999 & 0.8595 & Low & 0.9217 & Low & 1.0291 & Fairly High & 0.9771 & Low \\
\hline 2000 & 0.9534 & Low & 0.9504 & Low & 0.9661 & Low & 1.0563 & High \\
\hline 2001 & 0.9807 & Low & 0.0000 & Low & 0.9643 & Low & 0.9909 & Low \\
\hline 2002 & 0.9634 & Low & 0.9989 & Low & 1.0265 & Fairly High & 0.9221 & Low \\
\hline 2003 & 0.9901 & Low & 0.9845 & Low & 1.0265 & Fairly High & 0.9611 & Low \\
\hline 2004 & 1.0120 & Fairly High & 1.1000 & High & 1.0421 & Fairly High & 1.0057 & Fairly High \\
\hline 2005 & 1.0514 & High & 1.1020 & High & 1.0049 & Fairly High & 1.0376 & Fairly High \\
\hline 2006 & 1.1394 & High & 1.1027 & High & 1.0337 & Fairly High & 1.0262 & Fairly High \\
\hline 2007 & 1.2126 & High & 1.0826 & High & 1.0306 & Fairly High & 1.0240 & Fairly High \\
\hline 2008 & 1.1624 & High & 1.0833 & High & 1.0306 & Fairly High & 1.0181 & Fairly High \\
\hline 2009 & 1.1974 & High & 1.0807 & High & 1.0280 & Fairly High & 1.0225 & Fairly High \\
\hline 2010 & 1.2046 & High & 1.0879 & High & 1.0753 & High & 1.0847 & High \\
\hline Mean & 1.0172 & Fairly High & 0.9409 & Low & 1.0038 & Fairly High & 1.0016 & Fairly High \\
\hline
\end{tabular}

High degree of sorghum crop failure is experience from 2004 - 2010 (Table 2). In evaluating the differences in the annual yield sensitivity index in the different years, findings reveal that there is significant difference in the Sensitivity Index of sorghum yield from $1996-2010\left(\mathbf{X}^{2}\right.$ table values at $0.05(5 \%)$ and $0.01(1 \%)$ are 23.685 and 29.141 respectively are lower than the calculated value (227.693).

Result depicts that sensitivity index of rice yield failure is low from 1996 - 2001. From the year 2002 - 2010 the degree of rice yield failure is observed to be fairly high (see table 2). In evaluating the differences in the annual yield sensitivity index of the years, findings show that there is significant difference in the Sensitivity Index of rice yield from $1996-2010\left(\mathbf{X}^{2}\right.$ table values at $0.05(5 \%)$ and $0.01(1 \%)$ are 23.685 and 29.141 respectively are lower than the calculated value (60.623).

The sensitivity index of millet yield failure is low between1996-2003 but a high level degree of crop failure in the year 2000. The degree of millet yield failure is fairly high from the year 2004 to 2010 (Table 2). In evaluating the differences in the annual yield sensitivity index of the years, findings show that there is significant difference in the Sensitivity Index of millet yield from 1996 $2010\left(\mathbf{X}^{2}\right)$ table values at $0.05(5 \%)$ and 0.01 
$(1 \%)$ are 23.685 and 29.141 respectively are lower than the calculated value (34.119).

Cereals require specific photoperiods for optimum yield and any change in this photoperiod tends to increase cereals sensitivity to the impact of climate change/variability. This is likely the cause for an upward trend in the sensitivity of cereals to climate change/variability in the FCT. Change/variability of temperature usually affects cereals vegetative growth as well as reproductive development which are only at a specific period. Generally, cereals yield decreases in developing countries and yield increases in developed countries due to sensitivity of the cereals to climate variability (Parry et al., 2004). All the cereals (maize, sorghum, rice and millets) studied are sensitive to rainfall and temperature change/variability. Agreeing with the findings of this study, Universal Ecological Fund (2011) assert that countries with expected increase in maize, rice production and yield in the face of climate change/variability include; China, United States, Indonesia, Vietnam, Philippines, Japan, Thailand, Myanmar, Cambodia, Republic of Korea, Lao Peoples Democratic Republic. In the other hand, countries with expected decrease in yield and production for maize and rice as a result in change/variability in climate include Nigeria, India, Brazil, Egypt, Pakistan, Bangladesh, Nepal, Sri Lanka and Madagascar.

Universal Ecological Fund (2011) equally opined that countries with expected increase in sorghum yield and production include China, United States, Indonesia, Brazil, Canada, Argentina, Vietnam, Japan, Serbia, Paraguay, Bolivia, Uruguay and Democratic People's Republic of Korea. Countries with expected decrease in sorghum production include India, Nigeria, Russian Federation, Ukraine, Italy, Iran and South Africa. Equally observed by Universal Ecological Fund (2011) they opined that in nearly all West
African countries, the increase in cereals in quantity produced is due more to an increase in the amount of land sowed with cereals than to any significant improvement in yields. According to the Central Bank of Nigeria's statistics, the land devoted to growing cereals increased by $5 \%$ between 1990 and 2000, compared to an increase of $3 \%$ in average yields.

Crop failure in the FCT in the recent decade is likely due to the frequent occurrence of agricultural drought occasioned by erratic rainfall distribution and/or cessation of rain during the growing season as the greatest hindrance to increased yield of cereals which is more serious in the northern part of country (FCT inclusive) where most of the cereals are produced (Olaoye, 1999; Ismaila et al., 2010). In some cases terminal drought are being experienced by farmers in the same farm where flood equally visited are potential climatic disturbance increasing cereals sensitivity index in the Northern part of Nigeria (FCT inclusive) (Gana et al., 2000).

\section{Adaptive Capacity/Socioeconomic Indicators of Farmers to Climate Change/Variability}

Climate change adaptive capacity depends mainly on five farmers' livelihood assets: wealth, farm inputs, availability of infrastructures and institutions, potential for irrigation and literacy level (Temesgen et al., 2008). These are the most sited indicators of adaptation capacity of farmers to climate change and were the climate change adaptation capacity indicators considered in this study.

Results in this study pertaining adaptive capacity of farmers based on wealth consideration as an indices of adaptive capacity to climate change/variability depicts high adaptive capacity (1.07) among farmers in Bwari Area Council, fairly high (1.05) in Abuja Municipal Area Council (AMAC), Low (0.99) in Kwali Area Council, low 
(0.92) in Gwagwalada Area Council, low (0.83) in Kuje Area Council and low (0.67) in Abaji Area Council (Table 3).Lacks of money, shortage of labor, shortage of land are constraints associated with poverty and these reduce adaptive capacity to climate change among farmers. Adaptation to climate change is costly (Mendelson, 2004, Temesgen et al., 2011), and the need for intensive labor use may contribute to this cost. Farmers with insufficient family labour, financial backing to hire labour are likely to be restricted from climate change adaptation. Based on this, farmers in Bwari and Abuja Municipal Area Council are most likely to adapt to climate change strongly and farmers in Kwali, Gwagwalada and Abaji Area Council will be the most threatened in terms of wealth.

In considering farm inputs as an indices of adaptive capacity to climate change, adaptation capacity was recorded high (1.10) among farmers in Bwari Area Council, high (1.10) in AMAC, low (0.99) in Kwali Area Council, low (0.98) in Gwagwalada Area Council, low (0.84) in Kuje Area Council and low (0.62) among farmers in Abaji Area Council (Table 3). Based on infrastructural availability as indices of adaptation capacity to climate change, adaptation capacity was recorded high (1.14) among farmers in AMAC, high (1.07) in Bwari Area Council, low (0.95) in Gwagwalada Area Council, low (0.93) in Kwali Area Council, Low (0.86) in Kuje Area Council and Low (0.58) among farmers in Abaji Area Council. Irrigation potential is one of the prominent adaptive activities towards checking climate change among farmers. The potential for irrigation as an adaptive capacity among farmers is considered high (1.34) in Abaji Area Council, high (1.29) in AMAC, high (1.19) in
Bwari Area Council, fairly high (1.01) in Kuje Area Council, low (0.97) in Gwagwalada Area Council and low (0.96) in Kwali Area Council (table 3 below). Succinctly, farmers with higher irrigation potential e.g. those in Abaji Area Council, AMAC and Bwari Area Council, are more likely to adapt better to climate change based on higher irrigational potential than those in Gwagwalada and Kwali Area Council. The level of literacy as an indexes for adaptation capacity among farmers was unveiled to be high (1.23) in AMAC, high (1.21) in Bwari Area Council, fairly high (1.03) in Kuje Area Council, low (0.97) in Kwali Area Council, low (0.97) in Gwagwalada Area Council and low (0.62) in Abaji Area Council.

The mean adaptation capacity among farmers shows that, farmers in Abuja Municipal Area Councils have the highest (1.16) adaptation capacity followed by farmers in Bwari Area Councils having 1.12. Low adaptation capacity is recorded among farmers in Kwali Area Council having 0.97, Gwagwalada Area Council having 0.95, Kuje Area Council 0.91 and the least (0.77) was recorded in Abaji Area Council (see table 3). Temesgen et al., (2011) assert that higher level of education is believed to be associated with access to information on improved technologies and higher productivity. Researches indicate that there is a positive relationship between the education level of household head/inhabitants and the adoption of improved technologies and adaptation to climate change (Maddison, 2006; Temesgen et al., 2011). Therefore, farmers with higher levels of education those in AMAC, Bwari Area Council, Kuje Area Council are more likely to adapt better to climate change based on higher literacy level than those Abaji, Gwagwalada and Kwali Area Councils. 
Table 3: Adaptation Capacity of Farmers Based on Area Councils

\begin{tabular}{|c|c|c|c|c|c|c|c|}
\hline \multirow{2}{*}{\multicolumn{2}{|c|}{ ADAPTIVE CAPACITY VARIABLES }} & \multicolumn{6}{|c|}{ Area Councils } \\
\hline & & AMAC & Abaji & $\mathrm{G} / \mathrm{L}$ & Kuje & Kwali & Bwari \\
\hline $\mathrm{A}$ & $\begin{array}{l}\text { Wealth Consideration as Indices of Adaptive } \\
\text { capacity to climate change }\end{array}$ & 1.05 & 0.67 & 0.92 & 0.83 & 0.99 & 1.07 \\
\hline B & $\begin{array}{l}\text { Farm Inputs Consideration as Indices of Adaptive } \\
\text { capacity to climate change }\end{array}$ & 1.10 & 0.62 & 0.98 & 0.84 & 0.99 & 1.10 \\
\hline & $\begin{array}{l}\text { Infrastructural availability as Indices of adaptive } \\
\text { capacity to climate change }\end{array}$ & 1.14 & 0.58 & 0.95 & 0.86 & 0.93 & 1.07 \\
\hline $\mathrm{D}$ & $\begin{array}{l}\text { Irrigation Potentials Consideration as Indices of } \\
\text { Adaptive capacity to climate change }\end{array}$ & 1.29 & 1.34 & 0.97 & 1.01 & 0.96 & 1.19 \\
\hline & $\begin{array}{l}\text { Literacy level as consideration for adaptation } \\
\text { capacity to climate change }\end{array}$ & 1.23 & 0.62 & 0.97 & 1.03 & 0.98 & 1.21 \\
\hline $\mathrm{Me}$ & & 1.16 & 0.77 & 0.95 & 0.91 & 0.97 & 1.12 \\
\hline
\end{tabular}

Note: $0-0.99=$ Low Adaptation, $1-1.05=$ Fairly High Adaptation, 1.06 and Above $=$ High Adaptation

Post Adaptation Vulnerability of Cereals to Climate Change/Variability

In this study, the post adaptation vulnerability of maize production to rainfall is low in AMAC and Bwari Area Council with 0.81 and 0.85 vulnerability indexes respectively. Fairly high vulnerability is observed in Gwagwalada and Kwali Area Councils with 1.02 and 1.00 vulnerability indexes respectively. High vulnerability is observed in Abaji (1.20) and Kuje (1.06) Area Councils. In the other hand, the post adaptation vulnerability of maize yield in relation to temperature shows that, vulnerability is low (0.84) in AMAC, low (0.80) in Bwari Area Council, high (1.23) in Abaji Area Council. In Gwagwalada, Kuje and Kwali Area Council the vulnerability is fairly high having 1.05, 1.00 and 1.03 vulnerability indexes respectively (Table 3 ). Thus post adaptation vulnerability of maize to climate change/variability is high in all the area councils in the FCT except for AMAC and Bwari Area Councils.

Table 3: Maize Vulnerability Index

\begin{tabular}{|c|c|c|c|c|c|c|}
\hline $\begin{array}{l}\text { Area } \\
\text { Council }\end{array}$ & $\begin{array}{ll}\text { Rainfall } & \text { Exp. } \\
\text { Index } & \\
\end{array}$ & $\begin{array}{l}\text { Maize } \\
\text { Index }\end{array}$ & Sens. & $\begin{array}{l}\text { Adaptive } \\
\text { Capacity }\end{array}$ & $\begin{array}{l}\text { Vulnerability } \\
\text { Index }\end{array}$ & Decision \\
\hline AMAC & 0.953 & 1.017 & & 1.16 & 0.81 & Low Vulnerability \\
\hline ABAJI & 0.953 & 1.017 & & 0.77 & 1.20 & High Vulnerability \\
\hline G/LADA & 0.953 & 1.017 & & 0.95 & 1.02 & Fairly High Vulnerability \\
\hline KUJE & 0.953 & 1.017 & & 0.91 & 1.06 & High Vulnerability \\
\hline KWALI & 0.953 & 1.017 & & 0.97 & 1.00 & Fairly High Vulnerability \\
\hline BWARI & 0.953 & 1.017 & & 1.12 & 0.85 & Low Vulnerability \\
\hline & $\begin{array}{l}\text { Temperature } \\
\text { Exp. Index }\end{array}$ & $\begin{array}{l}\text { Maize } \\
\text { Index }\end{array}$ & Sens. & $\begin{array}{l}\text { Adaptive } \\
\text { Capacity }\end{array}$ & $\begin{array}{l}\text { Vulnerability } \\
\text { Index }\end{array}$ & Decision \\
\hline AMAC & 0.992 & 1.017 & & 1.16 & 0.84 & Low Vulnerability \\
\hline ABAJI & 0.992 & 1.017 & & 0.77 & 1.23 & High Vulnerability \\
\hline G/LADA & 0.992 & 1.017 & & 0.95 & 1.05 & Fairly High Vulnerability \\
\hline KUJE & 0.992 & 1.017 & & 0.91 & 1.00 & Fairly Vulnerability \\
\hline KWALI & 0.992 & 1.017 & & 0.97 & 1.03 & Fairly High Vulnerability \\
\hline BWARI & 0.992 & 1.017 & & 1.12 & 0.80 & Low Vulnerability \\
\hline
\end{tabular}

Note: 0 - 0.99 = Low Vulnerability, 1 - 1.05 Fairly High Vulnerability, 1.06 and above = High Vulnerability 
Result on sorghum post adaptation vulnerability to climate change/variability shows that vulnerability in relation to rainfall is low in all the area councils in the FCT except for Abaji Area Council having high (1.12) vulnerability. In relation to temperature, sorghum yield in Abaji Area Council equally record high vulnerability (1.16), Kuje Area Council depicts fairly high (1.02) vulnerability and low vulnerability is observed for AMAC, Gwagwalada, Kwali and Bwari Area Councils. Sorghum is more vulnerable to temperature variability than rainfall variability (Table 4 ).

The post adaptation vulnerability of rice yield to rainfall is low in AMAC and Bwari Area Council with vulnerability indexes of 0.70 and 0.84 respectively. High vulnerability (1.19) is recorded for Abaji Area Council and fairly high vulnerability is observed for Gwagwalada (1.0), Kuje (1.04) and 1.02 in Kwali Area Councils. The post adaptation vulnerability of rice to temperature is low in AMAC and Bwari having 0.84 and 0.88 vulnerability indexes respectively. Abaji and Kuje Area Council depict high vulnerability with vulnerability indexes at 1.22 and 1.09 respectively. Gwagwalada and Kwali show a fairly high vulnerability with 1.05 and1.02 vulnerability indexes respectively (Table 5).

Table 4: Sorghum Vulnerability Index

\begin{tabular}{|c|c|c|c|c|c|c|}
\hline $\begin{array}{l}\text { Area } \\
\text { Council }\end{array}$ & $\begin{array}{l}\text { Rainfall } \\
\text { Index }\end{array}$ & Exp. & $\begin{array}{l}\text { Sorghum Sens. } \\
\text { Index }\end{array}$ & $\begin{array}{l}\text { Adaptive } \\
\text { Capacity }\end{array}$ & $\begin{array}{l}\text { Vulnerability } \\
\text { Index }\end{array}$ & Decision \\
\hline AMAC & 0.953 & & 0.941 & 1.16 & 0.73 & Low Vulnerability \\
\hline ABAJI & 0.953 & & 0.941 & 0.77 & 1.12 & High Vulnerability \\
\hline G/LADA & 0.953 & & 0.941 & 0.95 & 0.94 & Low Vulnerability \\
\hline KUJE & 0.953 & & 0.941 & 0.91 & 0.98 & Low Vulnerability \\
\hline KWALI & 0.953 & & 0.941 & 0.97 & 0.92 & Low Vulnerability \\
\hline \multirow[t]{2}{*}{ BWARI } & 0.953 & & 0.941 & 1.12 & 0.77 & Low Vulnerability \\
\hline & $\begin{array}{l}\text { Temp. } \\
\text { Index }\end{array}$ & Exp. & $\begin{array}{l}\text { Sorghum Sens. } \\
\text { Index }\end{array}$ & $\begin{array}{l}\text { Adaptive } \\
\text { Capacity }\end{array}$ & $\begin{array}{l}\text { Vulnerability } \\
\text { Index }\end{array}$ & Decision \\
\hline AMAC & 0.992 & & 0.941 & 1.16 & 0.77 & Low Vulnerability \\
\hline ABAJI & 0.992 & & 0.941 & 0.77 & 1.16 & High Vulnerability \\
\hline G/LADA & 0.992 & & 0.941 & 0.95 & 0.98 & Low Vulnerability \\
\hline KUJE & 0.992 & & 0.941 & 0.91 & 1.02 & Fairly High Vulnerability \\
\hline KWALI & 0.992 & & 0.941 & 0.97 & 0.96 & Low Vulnerability \\
\hline BWARI & 0.992 & & 0.941 & 1.12 & 0.81 & Low Vulnerability \\
\hline
\end{tabular}

Note: 0 - 0.99 = Low Vulnerability, 1 - 1.05 Fairly High Vulnerability, 1.06 and above High Vulnerability
Millet is the least produced cereals in the FCT. The post adaptation vulnerability of millet is not farfetched from the findings of other cereals. Millet in AMAC show low (0.70) vulnerability to change/variability in rainfall, low vulnerability (0.99) of millet yield to change in rainfall is recorded in Kwali Area Council and in Bwari Area Council millet vulnerability to change/variability in rainfall is low (0.84). The vulnerability of millet to change in rainfall is high (1.18) in Abaji Area Council. Fairly high vulnerability is recorded in Gwagwalada and Kuje Area Councils with indexes of 1.00 and 1.04 respectively. The post adaptation vulnerability of millet yield to change/variability in temperature is not farfetched from what was obtained in other earlier discussed cereals. Low vulnerability of millet to change in temperature was recorded in AMAC and Bwari Area Council having vulnerability indexes of 0.83 and 0.87 respectively. High vulnerability of millet to change/variability in temperature is recorded in Abaji and Kuje Area Councils with vulnerability indexes of 1.22 and 1.08 respectively. Gwagwalada Area Council recorded 1.05 and Kwali Area Council recorded 1.02 vulnerability indexes which depicts fairly high vulnerability index (Table 6). 
Table 5: Rice Vulnerability Index

\begin{tabular}{|c|c|c|c|c|c|}
\hline Area Council & $\begin{array}{ll}\text { Rainfall } & \text { Exp. } \\
\text { Index } & \end{array}$ & $\begin{array}{l}\text { Rice } \\
\text { Sens. } \\
\text { Index }\end{array}$ & $\begin{array}{l}\text { Adaptive } \\
\text { Capacity }\end{array}$ & $\begin{array}{l}\text { Vulnerability } \\
\text { Index }\end{array}$ & Decision \\
\hline AMAC & 0.953 & 1.004 & 1.16 & 0.70 & Low Vulnerability \\
\hline ABAJI & 0.953 & 1.004 & 0.77 & 1.19 & High Vulnerability \\
\hline G/LADA & 0.953 & 1.004 & 0.95 & 1.00 & Fairly High Vulnerability \\
\hline KUJE & 0.953 & 1.004 & 0.91 & 1.04 & Fairly High Vulnerability \\
\hline KWALI & 0.953 & 1.004 & 0.97 & 1.02 & Fairly Vulnerability \\
\hline \multirow[t]{3}{*}{ BWARI } & 0.953 & 1.004 & 1.12 & 0.84 & Low Vulnerability \\
\hline & Temperature & Rice & Adaptive & Vulnerability & Decision \\
\hline & Exp. Index & $\begin{array}{l}\text { Sens. } \\
\text { Index }\end{array}$ & Capacity & Index & \\
\hline AMAC & 0.992 & 1.004 & 1.16 & 0.84 & Low Vulnerability \\
\hline ABAJI & 0.992 & 1.004 & 0.77 & 1.22 & High Vulnerability \\
\hline G/LADA & 0.992 & 1.004 & 0.94 & 1.05 & Fairly High Vulnerability \\
\hline KUJE & 0.992 & 1.004 & 0.91 & 1.09 & High Vulnerability \\
\hline KWALI & 0.992 & 1.004 & 0.97 & 1.02 & Fairly High Vulnerability \\
\hline BWARI & 0.992 & 1.004 & 1.12 & 0.88 & Low Vulnerability \\
\hline
\end{tabular}

Note: 0 - 0.99 = Low Vulnerability, 1 - 1.05 Fairly High Vulnerability, 1.06 and above High Vulnerability

Table 6: Millet Vulnerability Index

\begin{tabular}{|c|c|c|c|c|c|c|c|}
\hline $\begin{array}{l}\text { Area } \\
\text { Council }\end{array}$ & $\begin{array}{l}\text { Rainfall } \\
\text { Index }\end{array}$ & Exp. & $\begin{array}{l}\text { Millet } \\
\text { Index }\end{array}$ & Sens. & $\begin{array}{l}\text { Adaptive } \\
\text { Capacity }\end{array}$ & $\begin{array}{l}\text { Vulnerability } \\
\text { Index }\end{array}$ & Decision \\
\hline AMAC & 0.953 & & 1.002 & & 1.16 & 0.70 & Low Vulnerability \\
\hline ABAJI & 0.953 & & 1.002 & & 0.77 & 1.18 & High Vulnerability \\
\hline G/LADA & 0.953 & & 1.002 & & 0.95 & 1.00 & Fairly High Vulnerability \\
\hline KUJE & 0.953 & & 1.002 & & 0.91 & 1.04 & Fairly High Vulnerability \\
\hline KWALI & 0.953 & & 1.002 & & 0.97 & 0.99 & Low Vulnerability \\
\hline \multirow{2}{*}{ BWARI } & 0.953 & & 1.002 & & 1.12 & 0.84 & Low Vulnerability \\
\hline & $\begin{array}{l}\text { Temp. } \\
\text { Index }\end{array}$ & Exp. & $\begin{array}{l}\text { Millet } \\
\text { Index }\end{array}$ & Sens. & $\begin{array}{l}\text { Adaptive } \\
\text { Capacity }\end{array}$ & $\begin{array}{l}\text { Vulnerability } \\
\text { Index }\end{array}$ & Decision \\
\hline AMAC & 0.992 & & 1.002 & & 1.16 & 0.83 & Low Vulnerability \\
\hline ABAJI & 0.992 & & 1.002 & & 0.77 & 1.22 & High Vulnerability \\
\hline G/LADA & 0.992 & & 1.002 & & 0.95 & 1.05 & Fairly High Vulnerability \\
\hline KUJE & 0.992 & & 1.002 & & 0.91 & 1.08 & High Vulnerability \\
\hline KWALI & 0.992 & & 1.002 & & 0.97 & 1.02 & Fairly High Vulnerability \\
\hline BWARI & 0.992 & & 1.002 & & 1.12 & 0.87 & Low Vulnerability \\
\hline
\end{tabular}

Note: $0-0.99=$ Low Vulnerability, $1-1.05$ Fairly High Vulnerability, 1.06 and above High Vulnerability

Generally, the findings in this study show that post adaptation vulnerability of cereals to climate change/variability are high in Gwagwalada, Abaji, Kwali and Kuje Area Councils of the FCT. In the other hand, the post adaptation vulnerability of cereals to climate change/variability is low in AMAC and Bwari Area Councils of the FCT. The low level of vulnerability of cereals to climate change/variability in AMAC and Bwari Area Councils is basically due to the high level of adaptive capacity in these two area councils. The results in this study are in line with that of Blaikie et al., (1993); Santiago (2001) observed that households that have access to resources and socioeconomic strength are less vulnerable the impact of climate change/variability. Although farmers with high adaptation capacity may experience greater losses (in absolute terms) than the poor, it can be argued that resource-rich households are 
more resilient in that they recover more quickly from a stress/stimulus.

As affirm in this study and asserted by Heru (2007), the variability in the growth time of cereals makes it more vulnerable to climate variability (temperature and rainfall variability). A shortened lifespan means the plant has to go through its critical reproduction period in a shortened time. Higher temperature and shifted seasonal variation, with no or slightly change of rainfall leads to drier land and shifted rainy season lead to lower crop production and shifted planting time (Peter and Philip, 2003; Heru, 2007). According to Saleemul (2003); Peter and Philip (2003) increase in temperature would have severe impacts on cereals production. A rise in temperature would reduce production of rice and wheat by $28 \%$ and $68 \%$ respectively. It was found that some rice species would enjoy a good harvest under severe climate change scenarios but yet be threatened climatic disturbances associated with climate variability such as drought and flood (Saleemul, 2003).

According to Rasmus and Misha (2011) overall vulnerability varies much less than exposure, sensitivity, and adaptive capacity which this study is quite agreeing to. This is because the sub-indexes of vulnerability tend to cancel each other out. Scholars in climatological study construct vulnerability index as a function of exposure to climate variability, sensitivity to the impacts of that exposure, and capacity to adapt to ongoing and future climatic changes. Exposure index can inform decisions about adaptation responses that might benefit an assessment of how and why vulnerability to climate change/variability varies yearly, regionally and it may prove a useful tool for policy analysts interested in how to ensure pro-poor adaptation particularly in developing countries. Parry et al. (2004) also opined that low-latitude areas including Africa would face decreased yields and increased risks due to climate change/variability. These crops (cereals inclusive) at low latitudes will have greater exposure to higher temperatures than crops at mid- and high latitudes. Thus, yields for grain crops, which are sensitive to heat, are more likely to decline at lower latitudes than at higher latitudes (Lan et al., 2007). The findings in this study affirm to these assertions.

Poor farmers in general are more vulnerable to climate variability and extremes compared to wealthy farmers. The small farmers in general tend to have good number of adaptation strategies but some of these strategies, however, like availing highinterest loan, are ineffective thereby only increasing their degree of vulnerability. Issues on of vulnerability and adaptation in developing country contexts often highlight the importance of poverty and inequality or differential resource access (Adger and Kelly, 1999). According to Ribot (1996), inequality and marginalization are among the most important determinants of vulnerability. This study affirms to the fact that marginalized area councils in the FCT such as Kwali, Kuje Abaji and to some extent Gwagwalada Area Council. If the farmers have significant resources available to them to cope with the yield decreases, then the overall vulnerability of the area may be low. The same yield decrease in an area with resource-limited farmers (in terms of technology or finance) may have a higher impact because of their lack of coping options. The same sensitivity level in this resource-poor area, lead to a higher level of vulnerability.

Concentration of small farms owned by low income farmers in the FCT are more in Gwagwalada, Abaji, Kuje and Kwali Area Council where vulnerability is high. Small farms are more vulnerable to change than larger farms because larger farms benefit from economies of scale. Thus, the 
vulnerability of farmers of low income and low literacy is considered to be greater than the vulnerability of high income and high literacy. This demonstrates the importance of adaptation in reducing vulnerability of farmers as depicted by this study and the findings of Berry et al. (2006). More diversified cereals production and less input dependent production systems were before the basis for coping with climate change. The losses of these alternatives increase farmers' vulnerability to climate variability. Particularly on those residing in vulnerable area councils of the FCT, climate variability imply serious production risks which will have more effect on small landholders with lower capacity to get the required resources to overcome these circumstances. Wehbe, (2005) agreed with this conclusion.

\section{Conclusion}

This study employed the integrated approach of climate change vulnerability Assessment. The application of integrated vulnerability method (biophysical and social determinants of vulnerability) method is useful because it uses rainfall and crop yield data to ascertain the characteristics of vulnerable and resilient cases in an area. This means that vulnerability in this research was viewed as a function of exposure, sensitivity and adaptive capacity which is not farfetched from the views of McCarthy et al. (2001) and Philip et al. (2011). The broad based nature of this model make it possible to ascertain the level of year to year exposure index using temperature and rainfall data, cereals (maize, sorghum, rice and millet) sensitivity index over the years was determine using cereals yield record and adaptive capacity of the area councils in the FCT were proffer using socioeconomic data of the inhabitants. These were used in determining the post-adaptation vulnerability of cereals yield to climate change/variability for every cereal in the six area councils of the FCT. The robust coverage of the study methodology that incorporate the biophysical conditions of the FCT through exploiting exposure index and cereals sensitivity index alongside adaptation capacity of the inhabitants of the six area councils in the FCT make the study encompassing.

Result in this study is concurring with that of Philip et al. (2011) depicting that the spatial distribution in the level of cereals vulnerability in the six area councils of the FCT is a product of adaptive capacity of the farmers in terms of literacy level, potential for irrigation, availability of infrastructures and availability of farm inputs. Based on these, vulnerability of cereals yield to climate change/variability in area councils with high adaptive capacity such as Bwari and AMAC is less. It is of paramount importance that neglected farming communities in area councils such as Gwagwalada, Kuje, Abaji and Kwali where adaptive capacity is low requires government policies and developmental projects that will boast literacy level, availability of infrastructures and availability of farm inputs. The requirement for adaptation is thriving and to a greater extent immediate in the Gwagwalada, Abaji, Kuje and Kwali Area Councils of the FCT which is the situation in most areas of developing countries where vulnerability is affirmed high and the impacts highly felt (Stern, 2006). Due to the nature of spatial variation in vulnerability in the FCT, policy makers need to tailor developmental policies to area councils where vulnerability is high especially within the large subsistence farming sector. This is by stimulating both agricultural intensification and diversification of livelihoods and enacting social programs and spending on health, education, farm input and welfare, which can help maintain and augment both physical and intangible human capital. 


\section{References}

Adakayi, P.E. (2000). Climate of FCT. In P.D. Dawam (ed) Geography of Abuja, Federal Capital Territory. Famous/Asanlu Publishers, Minna.

Balogun, O. (2001). The Federal Capital Territory of Nigeria: A Geography of Its Development. University of Ibadan Press Limited.

Barber, H., Jennifer, S., Ann, E.B. and William, G.A. (2003). Neighborhood Social Change and perceptions of Environmental Degradation. Popul. Environ., 25: 7-108.

Challinor, A., Wheeler, T., Garforth, C., Craufurd, P. and Kassam, A. (2009). Assessing the vulnerability of food crop systems in Africa to climate change. Climatic Change, Vol. 83 (3) 381-399.

Climate Change (2001). Impacts, Adaptation and Vulnerability, Cambridge University Press.

Etiosa, U. and Matthew, A. (2007). Coping with Climate Change and Environmental Degradation in the Niger Delta of Southern Nigeria.

Gbetibouo, G. A., Ringler, C. and Hassan, R. (2010). Vulnerability of the South African farming sector to climate change and variability: An indicator approach. Natural Resources Forum, 34: $175-187$

Hassan, S.M. (2008). Rainfall Variability and Agricultural Landuse Sustainability in Abuja FCT.Unpublished Ph.D. Thesis, Department of Geography, University of Abuja, Abuja.

Hassan, S.M., Celestine, E.I. Abdulai, J., Gerald, N. and Timothy, S. T. (2011). Assessing the Vulnerability of Agriculture to Climate Change in Nigeria.Draft of Strategies for Adaptation to Climate Change in Rural Sub-Saharan Africa: Targeting the Most Vulnerable. Funded by BM
Heru, S. (2007). A rapid vulnerability assessment method for designing national strategies and plans of adaptation to climate change and climate variability. Paper to be presented in the 2007 Amsterdam Conference on the Human Dimensions of Global Environmental Change, Vrije Universiteit, Amsterdam - Netherlands, 24-26 May 2007

IFPRI (International Food Policy Research Institute) (2009) Agriculture and Climate Change: An Agenda for Negotiation in Copenhagen. Gerald C. N., (Edited). International Food Policy Research Institute

IPCC (Intergovernmental Panel on Climate Change) (2001a). Climate change: The scientific basis. Contribution of Working Group I to The Third Assessment Report of the IPCC. Cambridge: Cambridge University Press.

IPCC (Intergovernmental Panel on Climate Change) (2001b). Climate change: Impacts, adaptation and vulnerability. Cambridge: Cambridge University Press

IPCC (2007). Climate change 2007: impacts, adaptation and vulnerability.Contribution of Working Group II to the Fourth Assessment Report of the Intergovernmental Panel on Climate Change. Parry ML, Canziani OF, Palutikof JP, Van der Linden PJ, Hanson CE, eds. Cambridge: Cambridge University Press.

Jan, S. and Anja, B. (2007). Indigenous Peoples and Climate Change. Report of Symposium 12-13 April 2007, Environmental Change Institute, Oxford Tyndall Centre Publication. Tyndall Centre for Climate Change Research, Oxford. 
Lecocq, F. and Shalizi, Z. (2007). How Might Climate Change Affect Economic Growth in Developing Countries? A Review of the Growth Literature with a Climate Lens.Policy Research Working Paper 4315. Development Research Group, Sustainable Rural and Urban Development Team, World Bank Publication.

Lobell, D.B., Burke, M.B., Tebaldi, C., Mastrandea, M.D., Falcon, W.P., Naylor, R.L. (2008). Prioritizing climate change adaptation needs for food security in 2030, Science. 319: 607-610.

Mendelsohn, R., Dinar, A., and Williams, L. (2006).The Distributional Impact of Climate Change on Rich and Poor Countries.Environment and Development Economics, 11: 159-178.

McCarthy, J.J., Canziani, O.F., Leary, N.A., Dokken, D.J. and White, K.S. (eds.): (2001) Climate Change 2001: Impacts, Adaptation and Vulnerability, Cambridge University Press, Cambridge.

Millennium Ecosystem Assessment (2005). Ecosystem and Human Well-Being: A Framework for Assessment. Washington DC: World Resource Institute.

Muyeye, C. and Jesper, S. (2010). Climate change adaptation in developing countries: issues and perspectives for economic analysis. A publication of International Institute for Environment and Development, United Kingdom

National Resources Defense Council (NRDC) (2007).Consequences of Global Warming. National Resources Defense Council Working Papers

Parry, M.L., Rosenzweig C., Iglesias, A., Livermore M. and Fischer, G. (2004). Effects of climate change on global food production under SRES emissions and socio-economic scenarios. Global Environmental Change. 14: 53-67

Philip, A., Evan, D.G.F., Andrew J.D., Lindsay C., Stringer and Elisabeth S., (2011). Mapping the vulnerability of crop production to drought in Ghana using rainfall, yield and socioeconomic data. Paper No. 25. Centre for Climate Change Economics and Policy Working Paper No. 55. SRI Papers (Online) ISSN 1753-1330

Rachel, B. (2008). The Impact of Climate Change on Minorities and Indigenous Peoples. Minority Rights Group International, United Kingdom

Saleemul, H., Atiq, R., Mama, K., Youba, S. and Hannah, R. (2003). Mainstreaming adaptation to climate change in least developed countries. Nottingham, UK

Scholze, M., Knorr, W., Arnel, N.W. and Prentice, I.C. (2006). A climate-change risk analysis for world ecosystems. Proceedings of the National Academy of Sciences, 103(35): 13116-12120.

Simelton, E., Fraser, E.D.G., Termansen, M., Forster, P.M., and Dougill, A.J. (2009). Typologies of crop-drought vulnerability: an empirical analysis of the socio-economic factors that influence the sensitivity and resilience to drought of three major food crops in China (1961-2001), Environmental Science and Policy, 12(4): 438-452.

Smiths, B. (2001).Adaptation to climate change in the context of sustainable development and equity. In McCarthy, J.J., Canziani, O., Leary, N.A., Dokken, D.J. and White, K.S., (eds), Climate change 2001: impacts, adaptation and vulnerability. IPCC Working Group II. Cambridge: Cambridge University Press, 877-912.

Stern, N. (2006). The Economics of Climate Change: The Stern Review. Cambridge University Press, Cambridge, UK. 
Post-Adaptation Vulnerability of Cereals to Rainfall and Temperature............... ISHAYA et al.

Temesgen, D., Rashid, M.H., Claudia, R. (2008). Measuring Ethiopian Farmers' Vulnerability to Climate Change Across Regional States. IFPRI Discussion Paper 00806, Environment and Production Technology Division

Temi, E.O. (2006). Flood Risk Assessment and Management in Nigeria. Selfers Educational Books Makurdi, Nigeria.
Universal Ecological Fund (2011). Climate Change: impacts, vulnerabilities and adaptation in developing countries. Effectively dealing with climate change in developing countries.

World Bank (2008). Biodiversity, Climate change and Adaptation: Nature-Based Solutions from the World Bank Portfolio. World Bank, Washington DC 